\title{
PELECEHAN SINISME MITRA TUTUR DALAM KONTEKS TUTURAN KELUARGA PENGEMIS DI TERMINAL ENAM BANJARMASIN
}

\author{
Rissari Yayuk \\ Balai Bahasa Kalimantan Selatan \\ Jalan A.Yani, Km 32,2, Loktabat, Banjarbaru, Kalimantan Selatan \\ Telepon 089691827674 \\ Pos-el penulis: yrissariyayuk@yahoo.co.id
}

\begin{abstract}
Abstrak
Pelecehan bukan hanya terjadi pada fisik, melainkan dapat dalam bentuk ucapan. Penelitian ini membahas masalah 1) bentuk pelecehan sinisme dari mitra tutur dalam komunikasi keluarga pengemis di Terminal Enam Banjarmasin. 2) fungsi pelecehan sinisme dari mitra tutur dalam komunikasi keluarga pengemis di Terminal Enam Banjarmasin. Tujuan dari penelitian ini adalah mendeskripsikan 1) bentuk pelecehan sinisme dari mitra tutur dalam komunikasi keluarga pengemis di Terminal Enam Banjarmasin, dan 2) fungsi pelecehan sinisme mitra tutur dalam komunikasi keluarga pengemis di Terminal Enam Banjarmasin. Metode penelitian ini adalah deskriptif kualitatif. Data utama ini adalah tuturan berbahasa Banjar yang dilakukan oleh keluarga pengemis di Terminal Enam Banjarmasin, Provinsi Kalimantan Selatan. Pengumpulan data dilakukan dari Januari hingga Maret 2019. Teknik yang digunakan adalah observasi, rekaman, catatan, dan dokumentasi. Analisis data dilakukan setelah mengumpulkan data, mengurutkan data, mengidentifikasi masalah, kemudian menganalisis data, dan menyajikan data. Presentasi dilakukan dengan menggunakan kata-kata biasa. Hasil penelitian menunjukkan bahwa bentuk pelecehan sinisme terjadi dalam bentuk sindiran, cemoohan, ancaman, dan kekasaran. Fungsi melecehkan sinisme dari mitra tutur yang berbicara di Terminal Enam Banjarmasin bersifat preventif. Kesimpulannya bahwa tujuan penyalahgunaan mitra tutur dikatakan sebagai upaya untuk mencegah penutur melakukan apa yang tidak diinginkan mitra tutur. Untuk mencapai hal ini, mitra tutur melakukan pelecehan melalui ucapan bersifat sinis dengan melanggar etika, strategi dan prinsip-prinsip kesopanan.
\end{abstract}

Kata kunci: pelecehan, sinisme, pengemis

\section{Harassing Through Cynical Comments by Conversational Opponents In The Context of Beggar Family Conversations at Banjarmasin's Terminal Six}

\begin{abstract}
Harassment does not only occur on the physical but can be in the form of speech. This study addresses the problem of 1) a form of cynical harassment of talking partners in the communication of beggars' families in Terminal Six Banjarmasin. 2) speech partner harassment function in beggar family communication in Terminal Six Banjarmasin The purpose of this study is to describe 1) the form of cynical harassment of speech partner in beggar family communication in Terminal Six Banjarmasin, and 2) harassment function of speech partner in beggar family communication at Terminal Six Banjarmasin. This research method is descriptive qualitative. The main data is the Banjar speech spoken by beggars' families in Terminal Six Banjarmasin, South Kalimantan Province. Data collection was carried out from January to March 2019. The techniques used were observation, recording, notes, and documentation. Data analysis is performed after collecting data, sorting data, identifying problems, then analyzing data, and presenting data. Presentations are made using ordinary words. The results showed that this form of cynicism took the form of satire, ridicule, threats, and rudeness. The function of harassing cynicism from speaking partners who speak at Terminal Six Banjarmasin is preventive. The conclusion is that the purpose of misusing the speech partner is said to be an attempt to prevent the speaker from doing what the partner does not want to do. To achieve this, the dialogue partner is harassed through cynical comments by violating ethics, strategy and politeness principles.
\end{abstract}

Keywords: harassment, cynicism, beggars 


\section{PENDAHULUAN}

Pelecehan berasal dari kata dasar leceh dan imbuhan pe-an. Leceh artinya sepele dan rendah. Pelecehan artinya membuat sesuatu menjadi terhina. Pelecehan dapat dilakukan melalui bahasa kala terjadi komunikasi antara penutur dan mitra tutur. Menurut A.D. Firman (2016: 56) bahwa bahasa adalah sistem lambang bunyi ujaran yang digunakan dalam berkomunikasi. Qodratillah, dkk. (2009: 341--342) menyebutkan leceh adalah remeh, sepele, hina, dan rendah. Rahardi (2016: 120) menyatakan bahwa pelecehan merupakan salah satu bentuk ketidaksantunan berbahasa yang membuat salah satu peserta tutur dibuat jengkel, bingung, sakit hati, terluka, bahkan dendam. Unsur pelecehan antara lain berwujud sindiran, cercaan, dan ejekan yang bersifat sinisme. Rahardi, dkk. (2009: 121--124) menyebutkan sinisme adalah pernyataan yang sifatnya mencerca, menyindir, dan mengejek dengan nuansa kata yang tabu, kejam, dan kasar yang disertai dengan nada, tekanan, intonasi, dan perangai yang tidak tepat.

Berdasarkan uraian di atas, yang dimaksudkan pelecehan sinisme mitra tutur dalam penelitian ini adalah perbuatan mencerca, menyindir, dan mengejek yang diwujudkan melalui ujaran kepada penutur ketika sebuah komunikasi terjadi. Akibat dari perbuatan tersebut, penutur menjadi tidak nyaman karena merasa terhina, diabaikan, diremehkan, dan direndahkan. Ketidaknyamanan yang dirasakan oleh penutur ini akibat pelecehan ujaran yang dilakukan mitra tutur.

Penelitian tentang pelecehan sinisme dilakukan mitra tutur dalam sebuah komunikasi dengan penutur. Peneliti mengambil data tuturan dalam keluarga pengemis yang ada di lingkungan Terminal Enam Kota Banjarmasin. Hal ini disebabkan pengamatan selintas, peneliti melihat komunikasi antarkeluarga pengemis di lingkungan Terminal Enam Banjarmasin ini sering terjadi konflik.
Akibatnya, tujuan komunikasi yang diharapkan menjadi terkendala. Padahal, pengemis ini meskipun bagian dari sampah masyarakat, mereka juga manusia yang memiliki emosi, harga diri, juga harusnya terikat oleh nilai-nilai kemanusiaan lainnya, seperti kesantunan berbahasa. Dalam berbicara antaranggota keluarga, tentu seseorang harus memperhatikan apa yang diucapkan. Ucapan untuk orang di luar dari yang bertutur merupakan sebuah tindakan verbal yang terikat norma sosial berbahasa. Pradopo (2012: 12) menyatakan sebuah tuturan merupakan tindakan sosial dan verba. Disebut tindakan sosial karena berhubungan dengan perbuatan penutur memosisikan diri sebagai anggota masyarakat yang baik dengan mitra tutur. Disebut tindak verbal karena tuturan adalah masalah penggunaan bahasa dalam berkomunikasi.

Berdasarkan latar belakang ini, peneliti mengkaji tentang masalah 1) bagaimana bentuk pelecehan sinisme mitra tutur dalam konteks tuturan keluarga pengemis di Terminal Enam Banjarmasin; dan 2) apa fungsi pelecehan sinisme mitra tutur dalam konteks tuturan keluarga pengemis di Terminal Enam Banjarmasin. Tujuan penelitian adalah mendeskripsikan 1) bentuk pelecehan sinisme mitra tutur dalam konteks tuturan keluarga pengemis di Terminal Enam Banjarmasin; 2) fungsi pelecehan sinisme mitra tutur dalam konteks tuturan keluarga pengemis di Terminal Enam Banjarmasin.

\section{TEORI}

Pelecehan sinisme merupakan bagian dari wujud kekerasan dalam sebuah peristiwa komunikasi. Penelitian mengenai kekerasan dalam komunikasi ini telah dilakukan oleh Nurvitawati (2013) dengan judul "Tindak Kekerasan Verbal dalam Rumah Tangga di Dukuh Karangtal, Desa Japanan, Kecamatan Cawas, Kabupaten Klaten". Hasil penelitian yang ditemukan adalah wujud tindak kekerasan verbal dari 
segi klasifikasi jenis tindak kekerasan verbal dalam rumah tangga. Wujud tindak kekerasan verbal dalam rumah tangga paling dominan digunakan adalah bentuk kalimat ekslamatif. Sementara itu, dari segi klasifikasi jenis tindak kekerasan verbal, yang paling dominan digunakan adalah verbal yang bersifat membantah.

Kemudian, Utami (2015) mengkaji

"Studi Mengenai Tindak Kekerasan Verbal dan Nonverbal oleh Guru Terhadap Siswa SMA Negeri di Surakarta Tahun Ajaran 2014/2015". Penelitian ini menemukan fakta bahwa terjadinya tindak kekerasan pada siswa merupakan bagian dari tindakan sosial secara rasional yang bersifat afektif. Dalam hal ini, tindak kekerasan dilakukan karena seorang guru memiliki kekuasaan di sekolah sehingga dapat dengan leluasa melakukan berbagai tindakan untuk menertibkan siswa. Tindakan ini akan berdampak pada pelaku dan korban kekerasan.

Dua penelitian di atas memiliki perbedaan dengan objek yang peneliti kaji. Penelitian pertama mengkaji tentang klasifikasi jenis kekerasan verbal dalam rumah tangga sedangkan penelitian kedua mengkaji tentang representasi kekuasaan guru di sekolah. Sementara itu, yang dibahas dalam penelitian ini adalah wujud dan fungsi pelecehan sinisme mitra tutur dalam keluarga pengemis di lingkungan Terminal Enam Banjarmasin.

Jumanto (2017: 50) menyatakan konteks adalah konsep yang dinamis bukan statis, yang harus dipahami sebagai lingkungan atau serangkaian kenyataan dunia yang senantiasa berubah, dalam arti luas dan diketahui bersama oleh partisipan (pengetahuan latar apa saja) yang memungkinkan para partisipan tersebut berinteraksi dalam proses komunikasi, dan ungkapan linguistik yang digunakan dalam interaksi mereka dapat dipahami dengan baik sesuai dengan latar belakang sosiokultural tertentu. Sperber dan Wilson Rusminto (2009: 29--54) menyatakan konteks tuturan tidak hanya meliputi lingkungan fisik, tuturan terdahulu, harapan masa depan, hipotesis ilmiah, keyakinan agama, ingatan akan anekdot, asumsi budaya, dan keyakinan akan keberadaan penutur.

Berdasarkan hal ini, ungkapan yang diujarkan sebagai sebuah tindak tutur dengan makna yang terdapat di dalamnya oleh peserta tutur dalam sebuah peristiwa komunikasi, dipengaruhi oleh ragam konteks yang melatarbelanginya. Hymes (1964), dalam Aslinda dan Syafyah (2010: 31--32) mengemukakan bahwa suatu peristiwa tutur harus memenuhi delapan komponen yang tersimpulkan dalam akronim SPEAKING. Kedelapan komponen tersebut adalah S: setting, berhubungan dengan waktu, tempat berbicara dan suasana bicara; P: participant, adalah pihak-pihak yang terlibat dalam pertuturan; $\mathrm{E}$ : end, merupakan maksud dan tujuan petuturan; A: act sequeces, adalah bentuk ujaran atau suatu peristiwa ketika seorang pembicara sedang mempergunakan kata-kata yang berisi pembicaraan; K: key, mengacu pada nada suara, cara dan ragam bahasa yang digunakan dalam menyampaikan pendapatnya dan cara mengemukakan pendapatnya, seperti sedih, gembira, serius; I: instrument, mengacu pada jalur bahasa yang digunakan seperti bahasa lisan, bahasa tulis, dan juga mengacu pada kode ujaran yang digunakan seperti oral, isyarat, tulisan, telegraf, dialek, dan lainlain; N: norm, yaitu aturan dalam berinteraksi misalnya yang berhubungan dengan aturan atau kesantunan memberi tahu, memerintah, bertanya, meminta maaf, basa-basi, mengkritik, dan sejenisnya. Hal ini berkaitan dengan hubungan sosial dalam sebuah masyarakat tutur; dan G: genre, yaitu bentuk penyampaian, seperti puisi, pepatah, doa.

Apapun ragam konteks yang melatarbelakangi sebuah tuturan sedapat mungkin tidak membuat sebuah ujaran mendatangkan konflik dalam mencapai tujuan komunikasi yang baik. (Chaer dan Agustina, 2010: 64) menyatakan tindak tutur sebagai gejala individual, bersifat 
psikologis, dan keberlangsungannya ditentukan oleh kemampuan bahasa si penutur dalam menghadapi situasi tertentu. (Chaer (2012: 27) menyatakan bahwa "Tindak tutur adalah tuturan dari seseorang yang bersifat psikologis dan yang dilihat dari makna tindakan dalam tuturannya itu". Maksudnya, tindak tutur merupakan ujaran yang berupa pikiran atau gagasan dari seseorang yang dapat dilihat dari makna tindakan atas tuturannya tersebut.

Apabila sebuah tuturan mendatangkan sebuah konflik yang berwujud pelecehan yang menimbulkan ketidaknyamanan dari salah satu atau semua peserta tutur seperti, merasa tidak dihargai, dihina, atau diabaikan, dan direndahkan, ada penyebab di balik tuturan tersebut. Penyebab yang dimaksud yaitu terjadinya pengindahan terhadap etika berbahasa atau pelanggaran terhadap prinsip kesantunan berbahasa. Chaer dan Agustina (2010: 172) menyatakan bahwa etika berbahasa erat kaitannya dengan pemilihan kode bahasa, norma-norma sosial, dan sistem budaya yang berlaku dalam suatu masyarakat. Etika berbahasa antara lain akan "mengatur " (1) apa yang harus kita katakan pada waktu dan keadaan tertentu kepada seorang partisipan tertentu berkenaan dengan status sosial dan budaya dalam masyarakat itu; (2) ragam bahasa apa yang paling wajar kita gunakan dalam situasi sosiolinguistik dan budaya tertentu; (3) kapan dan bagaimana kita menggunakan giliran berbicara kita, dan menyela pembicaraan orang lain; (4) kapan kita harus diam; (5) bagaimana kualitas suara dan sikap fisik.

Hymes, dalam Lubis (2015: 84), menyatakan kesantunan berbahasa dalam interaksi antara penutur dan petutur berdasarkan satuan pragmatis dan implikasi pragmatis dibangun dengan memperhatikan faktor linguistik dan nonlinguistik. Faktor nonlingustik mencakup latar, penutur, tujuan, isi tuturan, nada dan gaya tutur, sarana, norma dan tipe tutur. Hal ini didasarkan bahwa bahasa merupakan bagian yang tidak terpisahkan dari sistem sosial. (Wijana, 2010: 51) menyatakan prinsip kesopanan berhubungan dengan dua peserta percakapan, yakni diri sendiri dan orang lain. Diri sendiri adalah penutur dan orang lain adalah lawan tutur.

Sementara itu, Leech (dalam (Rusminto, 2009: 93) membagi aturan kesantunan menjadi enam prinsip. Terdiri atas maksim kearifan, maksim kedermawanan, maksim pujian, maksim kerendahatian, maksim kesepakatan, dan maksim kesimpatian. Brown dan Levinson dalam (Wijana, 2011: 135--136) terdapat beberapa strategi kesantunan dapat mendukung prinsip kesantunan berbahasa yang dapat dilakukan, seperti membesarbesarkan perhatian, persetujuan, dan simpati kepada pendengar, melibatkan penutur dan pendengar dalam aktivitas, menggunakan penanda identitas kelompok (bentuk sapaan, dialek, jargon, menunjukkan keoptimisan, menggunakan lelucon, memberikan tawaran atau janji ,memberikan pertanyaan atau meminta alasan, menyatakan hubungan secara timbal balik (resiprokal), dan memberikan hadiah (barang, simpati, perhatian, kerja sama) kepada mitra tutur.

\section{METODE}

Jenis penelitian adalah deskriptif kualitatif. Data utama dalam penelitian ini adalah tuturan para keluarga pengemis di sekitar Terminal Enam Banjarmasin, Provinsi Kalimantan Selatan. Pengambilan data dilakukan pada bulan Januari sampai dengan Maret 2019. Metode yang digunakan adalah observasi, catat, rekam , dan dokumentasi. Observasi dilakukan untuk menentukan tempat pengambilan data dan melakukan pengamatan langsung terhadap sumber data. Pencatatan dilakukan bersamaan dengan perekaman data tuturan di terminal. Dokumentasi dilakukan sebagai unsur penunjang data yang diperlukan.

Langkah analisis data adalah mengumpulkan data, memilah data, 
mengidentifikasi sesuai dengan permasalahan, analisis data, dan penyajian data. Penyajian dilakukan dengan menggunakan kata-kata biasa.

\section{HASIL DAN PEMBAHASAN}

Data percakapan yang diperoleh sejumlah 25 buah. Data ini berasal dari percakapan dalam keluarga pengemis di sekitar Terminal Enam Banjarmasin. Dari jumlah ini hanya diambil lima tuturan yang dianggap mewakili permasalahan. Kelima contoh tuturan pelecehan sinisme yang dilakukan mitra tutur dalam bentuk tutur dimaksud sebagai berikut.

\section{Bentuk pelecehan sinisme dari mitra tutur dalam komunikasi keluarga pengemis di Terminal Enam Banjarmasin}

Pelecehan sinisme ini berhubungan dengan respons negatif mitra tutur akan ujaran penutur, sehingga penutur merasa tidak nyaman karena telah dihina, dikasari, diremehkan, atau diabaikan. Mitra tutur melakukan tindak tutur yang melanggar kesantunan berbahasa kepada anggota keluarganya sendiri. Hal ini dapat dilihat pada percakapan berikut ini.

Data [1]

P: Ma aku dapat hudah, tapi sainiannya

'Bu saya sudah dapat, tetapi sedikit saja'

MT: Hah sainiannya hajakah, saharianan hudah, jaka paraya ikam turun, guring ja di rumah sana!

'Hah segini sajakah. Seharian penuh, lebih baik kamu tidak mengemis, tidur saja di rumah sana!'

Konteks: Tuturan terjadi di waktu sore menjelang magrib antara seorang anak $(\mathrm{P})$ dan ibunya (MT) di tepi jalan simpang empat Terminal Enam Banjarmasin.

Data [1] terdiri atas dua partisipan. Partisipan pertama yaitu penutur $(\mathrm{P})$ yang memiliki kedudukan dalam konteks ini sebagai anak dari partisipan kedua atau mitra tutur (MT). Mitra tutur memiliki posisi sebagai ibu penutur. Waktu terjadinya tuturan terjadi sore hari menjelang magrib di tepi jalan lampu merah Pal Enam Banjarmasin. Suasana hiruk pikuk kendaraan yang berlalu lalang menuju arah Terminal Pal Enam dan arah keluar kota Banjarmasin.

Penutur mendekati mitra tutur yang berdiri di tepi jalan. Raut wajah penutur terlihat kelelahan kala menyerahkan uang hasil mengemisnya kepada mitra tutur, sambil berujar Ma aku dapat hudah, tapi sainiannya ' $\mathrm{Bu}$ saya sudah dapat, tetapi sedikit saja'. Penutur menggunakan bahasa daerah Banjar. Nada bicaranya terdengar memelas. Meskipun mata penutur memandang wajah mitra tutur, raut wajahnya menunjukkan rasa penyesalan. Rasa penyesalan sekaligus mungkin ketakutan semakin ditunjukkan dengan keluarnya air mata dari penutur setelah mendengar ujaran mitra tutur kepadanya. Hah! Sainiannya hajakah? Saharianan hudah, jaka paraya ikam turun, guring ja di rumah sana! 'Hah! Segini sajakah? Seharian penuh, lebih baik kamu tidak mengemis, tidur saja di rumah sana!"

Ketika menerima hasil mengemis penutur dan mendengar nada memelas dari ujaran penutur, mitra tutur merespons dengan ujaran bernada tinggi, matanya sedikit melotot dengan wajah cemberut. Mitra tutur terlihat marah terhadap penutur. Mata melotot dengan wajah cemberut menunjukkan unsur suprasegmental yang menandakan adanya emosi tinggi dari mitra tutur terhadap penutur. Ujaran dengan yang menggunakan bahasa Banjar yang ber makna sebuah ujaran ketidakpercayaan pada hasil mengemis yang didapat penutur, padahal menurut mitra tutur kalau sudah seharian seperti itu, tentu hasil yang didapat akan banyak, tidak seperti yang didapat hari itu.

Ujaran yang dilakukan mitra tutur kepada penutur pada data [1] secara langsung ditujukan kepada penutur. Ujaran ini bermodus pertanyaan yang menunjukkan ketidakpercayaan mitra tutur kemudian digabung dengan kalimat 
berikutnya yang bermodus direktif yang menunjukkan kejengkelan mitra tutur. Kalimat pertama menggambarkan pertanyaan mitra tutur terhadap penutur "Hah! Segini sajakah? Kemudian kalimat berikutnya," Seharian penuh, lebih baik kamu tidak mengemis, tidur saja di rumah sana!".

Respons mitra tutur terhadap penutur merupakan wujud ketidaksantunan berbahasa karena melanggar prinsip kesantunan yang membuat penutur merasa dilecehkan. Mitra tutur tidak menjaga etika berbahasa sebab tidak mampu mengendalikan dirinya dengan cara berbicara santun kala menghadapi situasi dan kondisi saat itu. Penutur dan mitra tutur sudah seharian mengemis. Uang yang didapatkan dari penutur tidak sesuai dengan yang diharapkan. Rasa kecewa dan jengkel telah membuat ujaran yang tidak menyamankan penutur.

Penutur telah dilecehkan melalui ujaran sinisme mitra tutur. Hal ini ditandai dengan ujaran yang memiliki makna secara tidak langsung akan ketidakterimakasihan atas upaya yang dilakukan penutur selama sehari penuh beraktivitas di sekitar lampu merah Terminal Pal Enam Banjarmasin. Mitra tutur mengabaikan kebaikan bantuan penutur turut mengemis seharian penuh. Mitra tutur juga tidak menanggapi dan memberi simpati atas ujaran penutur yang mengakui keadaannya saat itu yang tidak bisa memperoleh uang lebih dari apa yang diharapkan mitra tutur.

Mitra tutur melanggar strategi kesantunan berbahasa dari segi memberi simpati kepada penutur. Mitra tutur juga melanggar prinsip kesantunan dari aspek maksim kearifan berbahasa. Mitra tutur tidak memilih ujaran yang lebih halus agar penutur tidak merasa dihina dan dipermalukan di hadapan orang banyak yang mendengar dan menyaksikan peristiwa tutur tersebut. Mitra tutur dari aspek keuntungan, telah memberikan rasa hormat dan keuntungan yang sebanyakbanyaknya terhadap diri sendiri tanpa memikirkan rasa hormat yang tidak diberikan sedikit pun kepada penutur yang juga anaknya berjenis kelamin perempuan dengan usia sekitar delapan tahunan tersebut.

Kesinisan mitra tutur terhadap penutur lebih dipertegas dengan ujarannya yang berbunyi Hah! Sainiannya hajakah?, Saharianan hudah, jaka paraya ikam turun, guring ja di rumah sana! "Hah! Segini sajakah? Seharian penuh, lebih baik kamu tidak mengemis, tidur saja di rumah sana!". Mitra tutur seakan-akan meremehkan upaya mengemis penutur yang memakan waktu seharian. Mitra tutur bahkan menyatakan bahwa lebih baik penutur pulang saja tidur di rumah seharian daripada mengemis, sebab apa yang diperoleh penutur tidak ada apaapanya sama dengan tidak mengemis sama sekali. Pernyataan ini pula mengandung makna ejekan kepada penutur yang menyamakan upaya penutur hari itu dalam mengemis sama saja dengan tidur di rumah. Bahkan, dengan tidur lebih baik daripada mengemis dengan hasil yang dianggap tidak ada apa-apanya bagi mitra tutur.

Data [2]

A: Lapar, Ma. Lapar

'Lapar, Bu. Lapar'

B: Lapar. Lapar. Lapar ha sana. Bacari hulu hanyar mainta makan, unda gin balum makan. Tahu kada, Nyawa?.

'Lapar. Lapar. Lapar ha sana. Mencari dahulu baru meminta makan, saya juga belum makan. Tahu tidak, Kamu?'.

Konteks: Tuturan terjadi antara seorang anak (P) dengan ibunya (MT) di waktu siang di depan masjid Terminal Enam Banjarmasin.

Berdasarkan konteks, data [2] terdiri atas dua peserta tutur. Peserta pertama yaitu penutur $(\mathrm{P})$ dan peserta kedua yaitu mitra tutur (MT). Kedua peserta ini terdiri atas anak dan ibu. Waktu terjadi tuturan adalah siang hari sekitar pukul setengah satu. Lokasi tuturan di depan masjid Terminal Enam Banjarmasin. 
Penutur ketika itu terlihat meringis menahan lapar. Baju yang dikenakannya tampak kotor, demikian pula badan dan kakinya. Penutur mendekati mitra tutur yang saat itu sedang duduk santai di bawah salah satu pohon di depan masjid Terminal Enam Banjarmasin. Mitra tutur sedang berkipas-kipas sambil sesekali menghitung uang receh hasil mengemis. Tiba-tiba penutur berkata "Lapar, Ma. Lapar. 'Lapar, Bu. Lapar'. Penutur mengungkapkan rasa laparnya dan berkeinginan agar mitra tutur membelikan makananan untuknya melalui data [2] ini.

Setelah mendengar ujaran penutur, mitra tutur langsung menghentikan aktivitasnya. Lalu berkata. Lapar. Lapar. Lapar ha sana. Bacari hulu hanyar mainta makan, unda gin balum makan tahu kada Nyawa. 'Lapar. Lapar. Lapar hasana. Mencari dahulu baru meminta makan, saya juga belum makan. Tahu tidak, Kamu". Mitra tutur mengujarkan kalimat ini dengan maksud agar penutur tidak mengucapkan apa yang diujarkan sebelum penutur berhasil mengumpulkan uang dari mengemis, dan mitra tutur sendiri juga belum makan sebab uang mengemisnya dirasa masih kurang untuk membeli makanan.

Nada suara mitra tutur meninggi kala mengujarkan tuturan. Terlihat rona merahnya di wajah mitra tutur. Matanya juga mendelik tajam kepada penutur. Mitra tutur tampak emosi saat itu. Bahasa lisan daerah Banjar yang mitra tutur ujarkan diiringi dengan gerak tangan. Telunjuknya mengarah ke wajah penutur yang terlihat tertunduk dan menggaruk kepala. Mitra tutur melakukan tindak tutur perintah kepada penutur. Mitra tutur menyatakan agar penutur mencari uang dulu baru bisa mengatakan lapar kepadanya .

Mitra tutur secara langsung melecehkan penutur dengan ujaran yang sinis. Penutur terlihat merasa tidak nyaman atas respons dari mitra tutur. Penutur terus menangis meminta makan meskipun tidak dihiraukan.Terlihat rasa kecewa dan sedih di rasa penutur terhadap mitra tutur.
Mitra tutur mengabaikan penutur yang saat itu sudah waktunya makan. Tidak ada rasa simpati yang diberikan mitra tutur kepada penutur. Pikiran mitra tutur mungkin adalah dia sendiri belum makan kenapa penutur minta makan, sementara uang mengemis tidak mencukupi. Pandangan ini tidak berdasarkan kepada siapa penutur. Mitra tutur tidak melihat penutur sebagai anak sendiri yang mestinya tidak diragukan akan rasa laparnya. Mitra tutur juga tidak lagi melihat kebaikan penutur selama ini dengan setia menemaninya mengemis meskipun masih dalam usia sekolah.

Telah terjadi konflik dalam tuturan pada data [2]. Mitra tutur marah-marah, sementara penutur menangis seraya berkata lapar. Mitra tutur telah melanggar etika berbahasa dengan menunjukkan kualitas suara tinggi sebagai tanda adanya unsur emosi atau amarah. Mitra tutur bukannya menenangkan penutur dengan menggunakan strategi kesantunan berjanji, seperti akan memberi makan, melainkan sebaliknya, mitra tutur malah menggunakan pelanggaran prinsip kesantunan berbahasa yang arif dan dermawan. Mitra tutur tidak menggunakan kata-kata sopan untuk membuat penutur nyaman. Mitra tutur juga memberikan keuntungan yang maksimal kepada penutur, malah mitra tutur tidak mau berbagi hasil mengemisnya untuk membeli makanan sebagimana yang diharapkan penutur.

Kesinisan yang dilakukan mitra tutur ini didasari oleh keadaan mitra tutur sendiri yang saat itu merasa lapar. Mitra tutur juga merasa rugi jika membeli makanan sementara hasil mengemisnya dirasa kurang. Akibatnya, meskipun penutur atau anaknya tersebut dalam kondisi lapar, mitra tutur tetap sinis menanggapinya. Hal ini akibat mitra tutur melanggar strategi kesantunan berbahasa dari aspek membesar-besarkan perhatian, persetujuan, simpati, dan janji.

Mitra tutur tidak memperhatikan kesehatan penutur, jika penutur lapar 
akibatnya bisa sakit dan tidak bisa beraktivitas. Mitra tutur juga tidak memberi persetujuan atas apa yang diinginkan penutur. Rasa kasihan tidak dimiliki mitra tutur saat itu terhadap penutur padahal penutur sudah setengah hari mengemis membantu mitra tuur, dari pagi hingga lewat pukul dua belas. Mitra tutur juga tidak memberikan janji akan membelikan makanan tuturan terjadi sebagai tanda penghargaan atas bantuan penutur yang sudah ikut mengemis. Keadaan ini memperparah perasaan penutur karena dilecehkan (diabaikan dan direndahkan, tidak dihargai) oleh mitra tutur melalui ujaran yang sinis akibat pelanggaran strategi dan prinsip kesantunan berbahasa.

Data [3]

P: Nah, hari ini kita makan sakali hajalah siang, duitnya habis bayar ubat samalam. Abah ikam gin balum makan mulai sumalam.

'Nah, hari ini kita makan sekali saja ya siang, uangnya habis untuk bayar obat kemarin. Bapak kamu juga belum makan mulai kemarin'.

MT: Hah? Apa Ma? Sakali? Kada mau. Aku handak makan wayahinian jua. Mun sakali baik paraya sama sakali. Aku kada handak umpat bacari mun damintu

'Hah? Apa Ma? Sekali? Tidak mau. $\mathrm{Aku}$ ingin makan sekarang juga. Kalau sekali lebih baik tidak usah sama sekali. Aku tidak ikut mengemis kalau begitu'.

Konteks:Tuturan terjadi antara anak (MT) dengan ibunya (P) di dalam Terminal Enam Banjarmasin di pagi hari.

Tuturan [3] terjadi pada pagi hari di dalam Terminal Enam Banjarmasin. Peserta tutur terdiri atas dua orang partisipan, yaitu anak (MT) dan ibu (P). Waktu itu, kedua peserta tutur akan memulai aktivitas mengemis di sekitar terminal. Sambil mempersiapkan peralatan mengemis, kedua peserta tutur ini duduk di salah satu halte terminal. Tiba-tiba penutur berujar . Nah, hari ini kita makan sakali hajalah. Siang. Duitnya habis bayar ubat samalam. Abah ikam gin balum makan mulai sumalam. 'Nah, hari ini kita makan sekali saja ya. Siang. Uangnya habis untuk bayar obat kemarin. Bapak kamu juga belum makan mulai kemarin'.

Penutur menginformasikan bahwa mereka berdua hari itu hanya bisa makan satu kali saja, sebab uangnya tidak mencukupi kalau makan tiga kali. Uang pemerolehan mengemis sebelumnya sudah habis untuk membeli obat untuk salah satu anggota keluarga mereka. Ayah mitra tutur sendiri dikatakan penutur juga belum makan sejak kemarin sore. Ketika mendengar informasi ini, spontan mitra tutur menjawab dengan sinis Hah? Apa Ma? Sakali? Kada mau. Aku handak makan wayahinian jua. Mun sakali baik paraya sama sakali. Aku kada handak umpat bacari mun damintu. 'Hah? Apa Ma? Sekali? Tidak mau. Aku ingin makan sekarang juga. Kalau sekali, lebih baik tidak usah sama sekali. Aku tidak ikut mengemis kalau begitu'.

Pernyataan mitra tutur ini memiliki makna bahwa dia tidak terima kalau hari itu hanya makan satu kali, apalagi makannya di siang hari. Mitra tutur menginginkan saat itu juga dapat memperoleh makanan, sebab dia sudah lapar sekali. Kalau hanya sekali, menurutnya lebih baik tidak sama sekali. Bahkan, mitra tutur mengancam bahwa kalau penutur tidak membelikan dia makanan, mitra tutur tidak ikut mengemis hari itu. Apa yang dimaksudkan oleh mitra tutur ini diujarkan dengan cara marahmarah. Mata mitra tutur menatap tajam penutur yang tidak lain adalah ibunya sendiri. Mitra tutur merespons ujaran penutur langsung secara lisan yang mengandung pelecehan.

Pelecehan yang dimaksudkan di sini adalah, penutur merasa tidak dihargai sebagai ibu dari penutur. Penutur dengan sinis menanggapi apa yang diujarkan penutur, padahal mitra tutur sudah mengetahui kondisi keuangan dan 
kesehatan keluarganya selama ini. Terjadi konflik komunikasi di sini. Penutur merasa tersakiti di bawah ketidaksetujuan dan ancaman mitra tutur. Mitra tutur seakanakan tidak menerima niat baik di balik ujaran penutur. Mitra tutur bahkan merasa terganggu akan informasi yang dia terima dari penutur.

Terjadinya pelecehan melalui tuturan oleh mitra tutur kepada penutur ini diakibatkan adanya pelanggaran etika berbahasa. Mitra tutur mengabaikan perasaan penutur yang merasa sangat sakit hati atas perkataan dan ancamannya. Mitra tutur tidak bisa mengontrol ucapannya yang saat itu keluar dari emosi tinggi, akibatnya perkataan sinisnya dengan nada tinggi tersebut didengar oleh mitra tutur dan orang-orang sekitar terminal. Norma kesopanan berkata lembut sebagai seorang anak (MT) tidak dihiraukan. Akibatnya, penutur merasa direndahkan. Hal ini dapat dilihat pada diamnya penutur dengan mata berkaca-kaca terus berlalu meninggalkan mitra tutur yang saat itu masih cemberut wajahnya.

Terjadi pelanggaran prinsip kesantunan yaitu prinsip kerendahhatian dan kesepakatan. Mitra tutur tidak berupaya untuk merendahkan hatinya dengan bersuara rendah kepada penutur di tengah lalu lalang orang. Mitra tutur tidak berupaya menerima keadaan sebagai tanda kemaklumannya akan kondisi yang sedang terjadi alam keluarganya tersebut. Mitra tutur tidak menyepakati apa yang diujarkan penutur, akibat keegoan hatinya yang menyebabkan penutur meninggalkan tempat tanpa suara.

Kesinisan yang berwujud ujaran tidak pada tempatnya tersebut disebabkan pula oleh pelanggaran strategi kesantunan yaitu persetujuan dan simpati. Mitra tutur tidak menyetujui akan apa yang diinginkan penutur. Mitra tutur juga tidak bersimpati terhadap kondisi keluarganya. Mitra tutur seakan lupa kebaikan yang selama hidupnya telah dia terima dari penutur dan anggota keluarga yang lain, sehingga dengan mudah mengancam tidak mau mengemis lagi. Padahal dengan mengemislah keluarga mereka dapat bertahan hidup.

Data [4]

P: Aduh, Bah! Hadangi pang!

'Aduh, Yah! Tunggu!'

MT: Hadang. Hadang. Mata kamana, jadi sampai rabah

'Tunggu. Tunggu. Mata ke mana, jadi sampai jatuh'.

Konteks: tuturan terjadi antara istri $(\mathrm{P})$ dan suami (MT) di trotoar Terminal Enam Banjarmasin waktu senja hari.

Berdasarkan konteks tuturan, peristiwa tutur ini terjadi antara seorang istri (P) dengan suaminya (MT). Istrinya memanggil suaminya dengan sapaan $B a h$ atau Abah. Saat itu senja hari, Terminal Enam Banjarmasin sudah mulai sepi. Hujan baru saja selesai turun. Trotoar yang berlubang digenangi air.

Penutur sebagai salah satu partisipan tuturan tanpa sengaja kakinya tersandung di trotoar terminal. Setelah itu dia terpeleset, akibatnya badannya jatuh di atas trotoar. Penutur pun dengan meringis kesakitan mengeluarkan ujaran P: Aduh, Bah! Hadangi pang! 'Aduh, Yah! Tunggu!' Suaranya cukup nyaring sehingga membuat para penjalan kaki di terminal rata-rata menoleh memperhatikan kejadian itu.

Mendengar teriakan penutur, mitra tutur yang tampak berjalan dengan cepat di depan penutur tiba-tiba berhenti. Mitra tutur melihat penutur dalam kondisi duduk dengan kaki terentang bukannya menolong, melainkan berkata Hadang. Hadang. Mata kamana, jadi sampai rabah 'Tunggu. Tunggu.' Mata ke mana, jadi sampai jatuh'. Ujaran mitra tutur ini memiliki maksud bahwa kenapa penutur sampai jatuh, ke mana mata penutur diarahkan.

Nada bicara mitra tutur ini memiliki intonasi meninggi. Wajahnya tidak ramah. Dia hanya diam sambil memperhatikan penutur berdiri dengan upaya sendiri. Hingga akhirnya, penutur 
berjalan menyusul mitra tutur yang tampak tidak sabar ingin segera keluar dari terminal tersebut.

Cara berbicara mitra tutur menunjukkan kalau dia tidak senang akan apa yang diujarkan penutur. Nada sinis terlihat pada ujaran mitra tutur. Mitra tutur malah menyalahkan penutur karena jatuhnya tersebut akibat tidak menggunakan matanya secara benar. Mitra tutur malah menanyakan hal tersebut saat kondisi penutur masih dalam keadaan jatuh di trotoar.

Mitra tutur tidak bisa mengendalikan emosinya saat menyaksikan jatuhnya penutur. Mitra tutur mengeluarkan ujaran yang tidak menunjukkan rasa simpati kepada penutur. Malah dia berpandangan, kalau penutur tidak layak ditolong atau ditunggu karena jatuh akibat tidak bisa menjaga mata sendiri. Pandangan inilah menyebabkan terjadinya konflik komunikasi dalam data [4].

Konflik yang berwujud pelecehan melalui tuturan ini dapat dilihat pada ujaran mitra tutur terhadap penutur. Mitra tutur telah membuat penutur tidak nyaman. Penutur telah diindahkan, tidak dihiraukan, dan tidak dihargai sebagai istri mitra tutur yang saat itu membutuhkan pertolongan. Mitra tutur melanggar etika berbahasa melalui nada suara yang menggambarkan mitra tutur sedang marah kepada penutur. Anggukan wajah mendongak ke atas dan telunjuk beberapa kali di arahkan ke mata penutur merupakan bagian dari aspek fisik yang menunjukkan keangkuhan mitra tutur kepada penutur. Mitra tutur angkuh untuk memberikan pertolongan dan menanggapi ujaran penutur dengan lebih ramah, layaknya suami kepada istrinya. Mitra tutur mungkin beraanggapan akibat jatuhnya penutur mengakibatkan lambatnya langkah mereka ke luar dari Terminal Enam Banjarmasin yang saat itu sudah mulai sepi.

Terdapat pelanggaran strategi dan prinsip kesantunan berbahasa pada data [4]. Strategi kesantunan yang dilanggar mitra tutur yaitu tidak memberikan perhatian, simpati, dan persetujuan. Mitra tutur melalui ujaran sebagai wujud ungkapan linguistik dan sikapnya menunjukkan tidak adanya rasa perhatian dan simpati atas apa yang terjadi pada penutur. Mitra tutur juga tidak menyetujui permintaan penutur untuk menunggu. Adapun prinsip kesantunan yang dilanggar mitra tutur adalah maksim kerendahhatian dan kesimpatian. Mitra tutur tidak berupaya merendahkan hatinya untuk mengikuti apa yang diinginkan penutur. Mitra tutur juga tidak memberikan rasa simpati kepada penutur meskipun penutur berada dalam kondisi memprihatinkan.

Data [5]

P: Bah, panas. Aku ka pinggir lah.

'Ayah, panas. Aku ke tepi ya'.

MT: Panas. Panas. Baya panas saikit ha. Bagana sana, awas bila kapinggir, kalu ku pangkung.

'Panas'. Panas. Cuma panas sedikit saja. Tetap di sana! Awas bila ke tepi! Nanti kupukul'.

Konteks: Tuturan terjadi di trotoar lampu merah antara seorang anak $(\mathrm{P})$ dengan ayahnya (MT).

Data [5] dituturkan oleh dua partisipan. Partisipan pertama yaitu penutur yang dalam peristiwa ini memiliki kedudukan sebagai anak mitra tutur atau partisipan kedua. Penutur saat itu sedang melakukan aktivitas mengemis di bawah terik matahari siang. Karena merasa kepanasan dan kelelahan, penutur yang usianya sekitar sepuluh tahunan ini mengujarkan Bah, panas. Aku ka pinggir lah. 'Ayah, panas. Aku ke tepi ya'.

Penutur menyatakan kepada mitra tutur bahwa dia merasa kepanasan. Penutur meminta izin kepada mitra tutur untuk menepi. Mitra tutur mendengar ujaran tersebut merespons dengan nada tinggi. Panas. Panas. Baya panas saikit ha. Bagana sana, awas bila kapinggir, kalu ku pangkung 'Panas. Panas. Cuma panas sedikit saja. Tetap di sana! Awas bila ke tepi! Nanti kupukul'. Makna dari ujaran mitra tutur ini adalah mitra tutur 
merasa apa yang dikatakan penutur sangat berlebihan. Mitra tutur menganggap panas yang dirasakan oleh penutur tidaklah terlalu panas. Penutur diharuskan tetap di tempatnya. Kalau penutur ke tepi, mitra tutur mengancam akan memukul penutur nanti.

Ujaran sinis mitra tutur ini langsung ditujukan kepada penutur dengan emosi tinggi. Mitra tutur berinteraksi dengan penutur dengan cara melecehkan penutur. Penutur merasa tidak nyaman akan jawaban dari mitra tutur. Penutur terlihat cemberut dan beberapa kali mengusap keringatnya yang bercucuran.

Ujaran pelecehan ini dapat dilihat pada makna kalimat yang dituturkan mitra tutur. Mitra tutur seakan-akan tidak mempercayai akan apa yang diungkapkan penutur, mitra tutur mengindahkan keluhan dan permintaan penutur. Mitra tutur lebih mempertegas pelecehannya terhadap diri penutur dengan memberi ancaman keras. Ancaman yang membuat penutur tetap tidak meninggalkan tempatnya.

Emosi yang tinggi diungkapkan mitra tutur melalui ujaran pada data [5] kepada penutur. Mitra tutur tidak meredam amarahnya. Hasilnya, ujaran yang bernada tinggi begitu nyaring terdengar oleh pengendara yang saat itu kebetulan berhenti karena lampu merah. Kemungkinan penutur pun merasa dipermalukan dan tidak dihargai oleh mitra tutur.

Bentuk ketidaknyaman yang didapatkan penutur ini merupakan konflik yang terjadi pada tuturan [5]. Bentuk ketidaknyamanan akibat ujaran pelecehan yang dilakukan oleh mitra tutur tersebut karena dilatarbelakangi oleh pandangan mitra tutur yang mengindahkan kebenaran ucapan dari penutur. Pelanggaran etika berbahasa pun terjadi. Kualitas fisik mitra tutur dengan lototan mata dan wajah merah menandakan adanya unsur marah kala melakukan ujaran. Mitra tutur tidak mengontrol emosi dan ujaran yang dikeluarkannya.
Terdapat pelanggaran prinsip dan strategi kesantunan berbahasa. Mitra tutur telah melakukan ketidaksesuaian dengan prinsip kesantunan kearifan, kedermawanan, dan kesepakatan. Mitra tutur tidak arif dalam membuat ujaran yang santun kepada penutur sebagai anak sendiri. Mitra tutur juga tidak dermawan kepada penutur dengan menyepakati apa yang diinginkan penutur.

Sementara itu, strategi kesantunan yang dilanggar mitra tutur meliputi tidak memberikan perhatian, persetujuan, dan simpati. Mitra tutur dengan memberikan ujaran yang disertai ancaman menandakan tidak adanya rasa perhatian kepada penutur yang saat itu sedang kelelahan daan kepanasan. Ketidaksetujuan mitra tutur atas permintaan penutur menandakan tidak adanya rasa simpati terhadap penderitaan penutur.

\section{Fungsi Pelecehan Sinisme Mitra Tutur dalam Komunikasi Keluarga Pengemis di Terminal Enam Banjarmasin}

Berdasarkan data yang diperoleh, penggunaan ujaran sinisme sebagai bentuk pelecehan mitra tutur kepada penutur merupakan representasi kekuasaan yang dimiliki mitra tutur terhadap penutur. Fungsi yang terdapat dalam tuturan mitra tutur ini berbentuk preventif. Fungsi yang terdapat dalam ujaran sinisme ini dimaksudkan untuk mencegah penutur melakukan apa yang tidak diiinginkan mitra tutur. Mitra tutur dalam tuturan [1], [2], [3], [4], dan [5] telah melakukan tindakan preventif. Prevensi (Kamus Ilmiah Serapan Bahasa Indonesia, 565; 2005) yaitu pencegahan; tindakan menanggulangi secara dini. Dalam KBBI (2008: 1101) disebutkan preventif adalah bersifat mencegah, supaya jangan terjadi apa-apa.

Data [1] misalnya, mitra tutur membuat ujaran yang memiliki tujuan agar penutur menyadari bahwa apa yang diperolehnya hari itu sangat tidak mereka. Ketidakbermanfaatannya ini diungkapkan dengan sinis melalui ujaran yang 
bermakna bahwa hasil mengemis tersebut sia-sia saja sama saja dengan hasil tidur di rumah. Mitra tutur tidak menghargai sama sekali atas upaya penutur yang sudah seharian penuh bekerja ikut mencari uang dengan mengemis. Pada data [1] ini mitra tutur memberi respons atau tanggapan yang tidak menyenangkan. Mitra tutur berharap dengan ujaran sinisnya akan memmbuat penutur jera, sebab mitra tutur menghendaki hal itu tidak terjadi lagi.

Pada Data [2] mitra tutur tidak menanggapi ujaran penutur yang saat itu menyatakan bahwa dia dalam kondisi lapar dan menginginkan mitra tutur untuk membelikan makanan. Ujaran sinis dilakukan mitra tutur dengan makna mitra tutur juga belum makan sehingga tidak pantas penutur merasa lapar dan memberitahu tentang laparnya tersebut kepada mitra tutur, Apalagi hasil mengemis mereka belum memadai sehingga sayang kalau dibelikan makanan. Mitra tutur dalam data [2] melakukan tindak ujar yang mencegah penutur untuk membeli makanan sebelum menghasilkan uang yang dirasa mencukupi.

Selanjutnya, pada Data [3] penutur mengatakan bahwa mereka tidak bisa makan sebanyak tiga kali sehari sebab uangnya sudah terpakai. Oleh karena itu, cukup satu kali saja mereka berdua bisa makan. Mitra tutur menanggapi ujaran penutur dengan sinis yang disertai ancaman. Mitra tutur tidak mau mengikuti apa yang disarankan penutur, dia malah mengancam tidak akan ikut mengemis jika hari itu makan cuma satu kali saja. Pada data [3] ini kesinisan yang dilakukan mitra tutur sebagai upaya pencegahan agar penutur tidak melakukan apa yang dinyatakannya

Kemudian, pada Data [4] mitra tutur juga dengan sinis menanggapi permintaan penutur. Penutur meminta agar mitra tutur berhenti berjalan dan menunggunya, sebab dia dalam kondisi terpeleset dan jatuh di trotoar yang licin. Mitra tutur menganggap apa yang diminta penutur dengan segala kondisinya merupakan kesalahan penutur sendiri yang tidak ada hubungannya dengan mitra tutur. Pada data [4] ini menggambarkan mitra tutur mencoba untuk mengajarkan secara tidak langsung kepada penutur untuk "berhati-hati" agar tidak terjadi hal demikian lagi nanti.

Terakhir, pada Data [5] penutur memberitahu bahwa dia kepanasan dan kelelahan mengemis di tempat tersebut. Tanggapan mitra tutur memiliki makna bahwa apa yang dinyatakan penutur sangat berlebihan. Mitra tutur dengan sinis membuat ujaran yang disertai ancaman agar penutur tidak beranjak dari tempatnya. Padat data [5] ini mitra tutur juga melakukan tindak pencegahan agar penutur tidak melakukan apa yang diinginkannya melalui ujaran sinisnya tersebut. Mitra tutur menghendaki penutur tetap mengemis walau bagaimanapun keadaannya. Mitra tutur tidak memedulikan akan keadaan penutur yang memiliki posisi sebagai anaknya sendiri.

Semua data [1], [2], [3], [4], dan [5], melalui ujaran sinisme ini telah menunjukkan bahwa mitra tutur memiliki sifat otoriter. Mitra tutur tidak sedikit pun mau melaksanakan prinsip kesantunan dan strategi kesantunan berbahasa seperti adanya rasa simpati, kesepakatan dan perhatian. Mitra tutur memosisikan apa yang diujarkan dan dialami penutur bukanlah sesuatu yang pantas dihargai dan diindahkan. Mitra tutur memandang rendah penutur, meskipun penutur merupakan bagian dari keluarganya sendiri.

\section{PENUTUP \\ Simpulan}

Pelecehan sinisme mitra tutur dalam konteks tuturan keluarga pengemis di Terminal Enam Banjarmasin ini dilakukan oleh mitra tutur sebagai ibu kepada anaknya, anak kepada ibunya, suami kepada istrinya, dan ayah kepada anaknya. Bentuk pelecehan tersebut dalam wujud sindiran, ejekan, ancaman, dan kekasaran. Mitra tutur pada semua data 
pada umumnya menunjukkan sikap abai dan merendahkan kepada penutur dengan melakukan pelanggaran etika, strategi, dan prisinsip kesantunan berbahasa. Penutur menjadi terhina dan tidak dihargai oleh mitra tutur.

Fungsi pelecehan sinisme mitra tutur dalam konteks tuturan keluarga pengemis di Terminal Enam Banjarmasin berupa tindak preventif. Tindakan ini merupakan upaya pencegahan agar penutur tidak melakukan apa yang diinginkan. Apabila mitra tutur mengikuti ujaran penutur, keinginan mitra tutur tidak tercapai.

\section{Saran}

Penelitian ini memiliki data yang masih terbatas. Penting dilakukan penelitian yang berikutnya berdasarkan ragam teori pragmatik atau sosial. Hasil penelitian dapat menjadi referensi awal untuk penelitian selanjutnya.

\section{DAFTAR PUSTAKA}

A.D. Firman. (2016). "Estetika Bahasa dalam Tradisi Papaseng Masyarakat Bugis: Kajian Stilistika". Jurnal Telaga Bahasa. Vol. 4. No. 1. Juni 2016. Hal. 55--82. Gorontalo. Kantor Bahasa Gorontalo.

Aslinda dan Syafyah. (2010). Pengantar Sosiolinguistk. Bandung: PT Refika Aditama.

Pradopo. (2012). Bahasa Kekuasaan dan Kekerasan. Yogyakarta: Universitas Sanata Dharma.

Chaer, Abdul dan Agustina, L. (2010). Sosiolinguistik. Perkenalan Awal. Jakarta: Rineka Cipta.

Chaer, Abdul. (2012). Sosiolinguistik. Jakarta: Rineka Cipta.

Jumanto (2017). Pragmatik, Dunia Linguistik Tidak Selebar Daun Kelor. Yogyakarta: Morfolingua.

Lubis, H. H. (2015). Analisis Wacana Pragmatik. Bandung: Angkasa.

Nurvitawati, E. (2013). "Tindak Kekerasan Verbal dalam Rumah Tangga di Dukuh Karangtal, Desa Japanan,
Kecamatan Cawas, Kabupaten Klaten". Skripsi. Surakarta: FKIP UMS.

Qodratillah, Meity Taqdir, D. (2009).

TABI. Bandung: Departemen

Pendidikan Nasional.

Rahardi, Kunjana, D. (2016). Pragmatik. Jakarta: Erlangga.

Rusminto, N. E. (2009). Analisis Wacana Indonesia. (Buku Ajar). Lampung: Universitas Lampung.

Utami, A. W. (2015). "Studi Mengenai Tindak Kekerasan Verbal dan Nonverbal oleh Guru terhadap Siswa SMA Negeri di Surakarta Tahun Ajaran 2014/2015". Sosialitas, 5 (2), 1-15. Surakarta: FKIP UMS.

Wijana, I. D. P. (2010). Pragmatik. Surakarta: Yumna Pustaka. 
Telaga Bahasa Vol. 7, No. 2, Desember 2019: 181--194 